\title{
The impact of intensive high performance training on adult height of female artistic gymnasts: a retrospective study
}

CDD. 20.ed. 796.033

796.41

http://dx.doi.org/10.1590/1807-55092016000100087

\author{
Raul Alves FERREIRA-FILHO* \\ Dalmo Roberto Lopes MACHADO****** \\ Renato Francisco Rodrigues MARQUES ${ }^{* *}$ \\ Myrian NUNOMURA**
}

*Centro de Ciências Biológicas e da Saúde, Universidade Presbiteriana Mackenzie, São Paulo, SP, Brasil.

**Escola de Educação Física e Esporte de Ribeirão Preto, Universidade de São Paulo, Ribeirão Preto,

SP, Brasil.

${ }^{* * *}$ Escola de Enfermagem de Ribeirão Preto,

Universidade de São Paulo, Ribeirão Preto,

SP, Brasil.

anthropometric and maturational characteristics of female artistic gymnasts and to compare the adult target height with international standards of growth. A sample consisted of 23 elite Brazilian female former gymnasts was evaluated. From a historic retrospective, about 29.56 yrs. ago (average of all) they devoted themselves to the training for 9.3 (2.6) years, with a weekly 24.26 (4.2) training hours, and had been retired from competition around at 13.61 (5.12) years old. From the anthropometric data of the gymnasts (while still competing), their parents and their older sister (1) and younger sister (2), the target height was calculated by Tanner method $\{[($ father's height $-13 \mathrm{~cm})+$ mother's height $] \div 2\}$. Additionally, training history, age of menarche occurrence, and growth classifying in accordance with the international standards was recorded, aimed at comparisons. The average stature shown normal adult stature (NCHS), and some cases surpassed the standard 75th, 90th and 95th percentile. They are higher than their mother $(p=0.039)$, but not their sister $1(0.952)$ or sister $2(p=0.998)$, but the age of menarche was significantly later only than their sisters $1(p=0.008)$ and $2(p=0.017)$. According to the Brazilian percentiles reference (IBGE), the final height of the former gymnasts was always higher of the standard, slightly smaller than their sisters 2 (5th and 10th), but was taller than their mothers and sisters 1 . In conclusion, there is no evidence of artistic gymnastics high performance training having adverse effects on the final adult height.

KEY WoRDS: Growth; Biological maturation; Women's artistic gymnastics; High performance level; Sports training; Anthropometry.

\section{Introduction}

People generally have great admiration for Artistic Gymnastics (AG), regardless if they are involved in competitions or non-official exhibitions. Thus, two features that spectators tend to be most deeply impressed with in this sport are the complexity of the acrobatics and the height of the gymnasts. The gymnast's task is made considerably easier if he or she is light as well as strong ${ }^{1-4}$. Moreover, gymnastics is an 'appearance sport', an exhibition of the body, aesthetics and technique, which means that the attractiveness of the athlete's body and performance is relevant and a matter of evaluation in competition. The anthropometric characteristics of gymnasts seem to be related to scores, particularly among female gymnasts ${ }^{5-6}$.
Several health issues related to gymnastics (artistic and rhythmic) have been at the centre of ongoing debates for the last 15 years ${ }^{4}$. Among these issues are: body composition and its relation to a high volume of training ${ }^{7-8}$, combined with inadequate $\operatorname{diet}^{9-10}$; each growth phase for adult shortness and the effect that the growth in one phase has on another ${ }^{11}$; anthropometric geometry ${ }^{12-13}$ and also hormonal regulation, growth and sexual development ${ }^{14-15}$.

Studies have shown that, when comparing the height of athletes belonging to the same age group, those who dedicate themselves to the practice of volleyball, basketball, and swimming, for instance, tend to be considerably taller than those committed 
to AG. Moreover, that "even the average height of the population" can be higher than the average height of gymnasts ${ }^{12,16-18}$. Why do gymnasts portray this image? Would it be possible that the characteristics of training itself brought about such a phenomenon? Or, could it be merely a matter of natural selection in the sport? Literature regarding the growth potential of stature in children who are committed to the practice of AG seems to be of concern in some countries ${ }^{4,10,17,19-21 .}$.

Pubertal delays have been confirmed in artistic and rhythmic gymnastics, and these include high stress imposed by training intensity and the high number of competitions ${ }^{4}$, delayed puberty ${ }^{22}$, and differences in menarche age and menstruation irregularities ${ }^{2}$. In reality these findings did not try to discuss the growth and development issues as

\section{Method}

\section{Subjects}

The test group consisted of 23 former elite women artistic gymnasts, aged 21 to 42 (average age: 29.56 yrs), who committed to the AG practice for a period of five to 13 years (average of $9.3 \mathrm{yrs}$ ), with a weekly average of 24.26 training hours, and who have been retired from training and competition for about 13.61 (5.12) years. According to the Brazilian Gymnastics Confederation (CBG), during this period and considering all levels of competition, there were 164 affiliated gymnasts across the country. Thus, regarding the adult level, this test group represents the entire highest-level group that we had between the periods of 2007 and 2008 and was involved in the national and international official events.

The study adhered to the Helsinki Declaration and followed the guidelines and regulations governing Brazilian human research, and the agreement was made with the informed consent of the parents or guardians, and approved by the Ethics and Research Committee (2006/21) of the School of Physical Education and Sport, University of Sao Paulo.

\section{Anthropometric measures}

The gymnast's measurements of adult height, weight, and sitting height, were taken by a portable aluminium stadiometer (SannyES-2060, 115 to $210 \mathrm{~cm}$ range), via procedures standardized in the related to genetic factors, but as consequence of training stresses.

The anthropometric and maturational aspects are individual and depend mainly on the genetic and environmental factors to express themselves in the form of a phenotype ${ }^{10,20}$. In high performance training, the specific features (anthropometric) for the different sports - height, sitting height and size of limbs - have been given special attention by several scholars ${ }^{16,23-25}$. The maturational aspects, which have also been given attention due to their variations (early or late), are often attributed to the intensive training for elite performance in the different sports, particularly in $A^{5}, 8,21,26-27$. Thus, we seek to identify the potential impact of high performance training on the growth of female artistic gymnasts, considering the target height, the final adult height, hereditary and maturational factors.

literature ${ }^{28}$.The length of the leg was calculated using the difference between the heights and sitting height. The back arm span was also measured. The equation used for reported mid-parent target height (MPTH) was: target height $=$ (father's height $-13+$ mother's height) $/ 2 \mathrm{~cm}^{29}$. This represents a deviation of a minimum of $5 \mathrm{~cm}$ approximately $\mathrm{y}^{30}$ and a maximum of $8.5 \mathrm{~cm}$ in females ${ }^{31}$ in both directions.

\section{Relative's data}

Data regarding the gymnast's relatives, such as their fathers, mothers, sister $1(\mathrm{n}=17)$ and $\operatorname{sister} 2(\mathrm{n}=8)$, along with the menarche history, was recorded. The height was also recorded for additional information, according to the protocol utilized in such studies ${ }^{8,32}$.

\section{Training history}

Through a questionnaire, we obtained information regarding the time of competition (onset and duration), weekly hours of training, and retirement time. We also calculated the age of retirement in order to compare the effect on the current adult height.

\section{Maturational history}

A questionnaire was used in order to collect maturational data: age of the occurrence of menarche among the former gymnasts, their mothers, and sisters. 


\section{Growth status}

The adult height of the former gymnasts was organized according to the international standards of the National Center of Health Statistics - NCHS ${ }^{33}$ for height in centimeters for females 20 years and older, and the national 50th percentile set by the Brazilian Institute of Geography and Statistics ${ }^{34}$ for the stature of women aged 20-44 years (and 55-64 years for parents' height).

\section{Results}

Descriptive statistics are summarized in TABLE 1 , including confidence interval (CI) and normality test analysis for anthropometrics, maturational and training histories of former gymnasts and their relatives' information.

The average gymnastic adult's height was significantly greater than their mother $(\mathrm{p}=0.039)$, but not their sister $1(0.952)$ or sister $2(\mathrm{p}=0.998)$. The difference in the gymnast adult's height and the MPTH 4.0 (5.2) $\mathrm{cm}$ was also higher $(\mathrm{t}=3.651$;f $=22$, sig $=0.001)$ in pair wise comparison. On the other hand, the menarche occurred later than her sisters $(F=5.259 ; \mathrm{p}=0.003)$, but no different than their mothers. They were smaller than their fathers, but even the difference $(9.6 \mathrm{~cm})$ was less than the 13 $\mathrm{cm}$ expected for the gender difference ${ }^{7,29}$. In order to calculate the adult height, $17(73.91 \%)$ of the 23 former gymnasts surpassed the predicted value on an average of $6.2 \mathrm{~cm}$, and $6(26.09 \%)$ were an average $2.4 \mathrm{~cm}$ below what had been predicted, thus having the greatest difference of $4.8 \mathrm{~cm}$.

When comparing the height of former gymnasts with those of their sisters, we obtained opposing results at one time: seven former gymnasts were shorter $(5.6 \mathrm{~cm})$ in relation to their sisters 1 , while in seven other cases they were taller $(6.13 \mathrm{~cm})$. Only in one case did both sisters practice AG, the older one being 29 years old and $170 \mathrm{~cm}$ tall, and the younger one being 25 years old and $160 \mathrm{~cm}$ tall; both were elite athletes, with the younger sister expressively superior in terms of the results and

\section{Statistical procedures}

Statistical analyses were carried out using the SPSS 17.0 version. All values were expressed as means and standard deviations. The frequency of statistical analysis was performed to the average height of the gymnasts and their parents. The percentage values of national and international standards used to reference the height comparisons of gymnasts and their relatives. A regression analysis (stepwise) was used to identify the explanatory variables of final adult height (dependent variable).

prizes obtained in competitions. However, in all other comparisons, the differences observed were not statistically significant (TABLE 1).

TABLE 2 shows the relative distribution of the gymnast's, their mother's, and their sisters' adult heights, according to the international (NCHS) and Brazilian (IBGE) reference percentiles. In general, it was verified that the gymnasts' height was near to the international or national standards. In relation to the Brazilian values, their height was always greater, except in the 50th centile when they were slightly lower.

Among all the former gymnasts, $34.78 \%$ were above the international average for the 75 th percentile $(163.93 \mathrm{~cm}) ; 21.74 \%$ were above the average for the 90th percentile $(168 \mathrm{~cm})$, and $13.04 \%$ were above the average of the $95 \%$ percentile $(169.46 \mathrm{~cm})$. The gymnast's percentile of height was greater than their mother and sister 1 , on other hand the gymnasts' sisters 2 were taller in (expected) P5, P10, and P50 (only case).

Stepwise regression was conducted to explain the predictors of the adult height of the former gymnasts (TABLE 3). Despite 9 variables included in the analysis, only one model was able to explain the dependent variable (adult height). The training history was considered, however none component was shown to interfere in the adult stature composition.

According to the single model raised, MPTH alone was able to explain $34 \%$ of the variance of the final height of gymnasts. 
TABLE 1 - Descriptive statistics and test for normality in former high level female gymnasts.

\begin{tabular}{|c|c|c|c|c|c|}
\hline \multirow{2}{*}{ Variables $(n=23)$} & \multirow{2}{*}{ Min - Max } & \multirow{2}{*}{ Mean (SD) } & \multirow{2}{*}{ CI $(95 \%)$} & \multicolumn{2}{|c|}{ Shapiro-Wilk } \\
\hline & & & & value & $\mathbf{p}$ \\
\hline \multicolumn{6}{|l|}{ Anthropometrics } \\
\hline Adult height (cm) & $150.4-172.5$ & $160.6(6.6)$ & 157.8 to 163.5 & 0.95 & 0.350 \\
\hline Age (year) & $21.0-42.0$ & $29.6(5.7)$ & 27.1 to 32.0 & 0.96 & 0.439 \\
\hline Adult weight (kg) & $47.3-71.2$ & $57.6(5.7)$ & 55.1 to 60.0 & 0.94 & 0.199 \\
\hline $\mathrm{BMI}\left(\mathrm{kg} / \mathrm{m}^{2}\right)$ & $19.7-27.1$ & $22.3(1.8)$ & 21.6 to 23.1 & 0.94 & 0.206 \\
\hline Sitting Height $(\mathrm{cm})$ & $74.0-92.4$ & $85.8(4.0)$ & 84.0 to 87.0 & 0.94 & 0.194 \\
\hline Legs Length (cm) & $68.1-89.0$ & $74.8(5.0)$ & 72.7 to 77.0 & 0.93 & 0.088 \\
\hline Sitting height/legs length (ratio) & $0.9-1.3$ & $1.2(0.1)$ & 1.1 to 1.2 & 0.88 & 0.008 \\
\hline Sitting height/height (ratio) & $0.48-0.56$ & $0.54(0.02)$ & 0.53 to 0.54 & 0.86 & 0.004 \\
\hline \multicolumn{6}{|l|}{ Maturation history } \\
\hline Target heights $(\mathrm{cm})$ & $147.5-164.0$ & $156.6(4.6)$ & 154.6 to 158.6 & 0.96 & 0.431 \\
\hline Menarche occurrence (age) & $11.1-17.0$ & $14.1(1.6)$ & 11.1 to 17.0 & 0.96 & 0.364 \\
\hline \multicolumn{6}{|l|}{ Training history } \\
\hline Initial age of training (year) & $3.0-14.0$ & $7.7(2.6)$ & 6.56 to 8.84 & 0.96 & 0.395 \\
\hline Practice time (year) & $5.0-14.0$ & $9.3(2.6)$ & 8.1 to 10.4 & 0.95 & 0.256 \\
\hline Weekly training (hours) & $16.0-30.0$ & $24.3(4.2)$ & 22.4 to 26.1 & 0.92 & 0.081 \\
\hline Time out (year) & $4.0-26.0$ & $12.6(5.1)$ & 10.4 to 14.8 & 0.96 & 0.382 \\
\hline Age time out (year) & $10.0-25.0$ & $17.0(3.3)$ & 15.5 to 18.4 & 0.96 & 0.551 \\
\hline \multicolumn{6}{|l|}{ Relatives } \\
\hline Father Stature $(\mathrm{cm})$ & $160.0-186.0$ & $170.0(7.35)$ & 167.0 to 173.4 & 0.96 & 0.376 \\
\hline Mother Stature $(\mathrm{cm})$ & $148.0-164.5$ & $156.0(4.68)$ & 154.0 to 158.0 & 0.95 & 0.232 \\
\hline Sister1 Stature $(\mathrm{cm})$ & $147.0-168.0$ & $147.0(5.84)$ & 156.6 to 162.7 & 0.96 & 0.615 \\
\hline Sister2 Stature $(\mathrm{cm})$ & $153.0-166.0$ & $160.2(5.38)$ & 156.1 to 164.4 & 0.82 & 0.036 \\
\hline Mother Menarche (year) & $10.0-15.0$ & $12.96(1.49)$ & 12.3 to 13.6 & 0.92 & 0.077 \\
\hline Sister1 Menarche (year) & $10.9-15.0$ & $12.51(1.31)$ & 11.8 to 13.2 & 0.91 & 0.102 \\
\hline Sister2 Menarche (year) & $11.0-15.0$ & $12.25(1.30)$ & 11.2 to 13.3 & 0.86 & 0.106 \\
\hline Height - target difference $(\mathrm{cm})$ & $-4.8-15.5$ & $4.0(5.2)$ & 1.7 to 6.3 & 0.97 & 0.761 \\
\hline
\end{tabular}

TABLE 2 - References, adult height, centiles and frequencies of former gymnasts and her relatives.

\begin{tabular}{lcccccccccc}
\hline Centile & $\begin{array}{c}\text { NCHS } \\
\text { (USA) }\end{array}$ & $\begin{array}{c}\text { IBGE } \\
(\text { Brazil })\end{array}$ & $\begin{array}{c}\text { Gymnasts } \\
(\mathbf{n}=\mathbf{2 3})\end{array}$ & $\mathbf{n}(\%)$ & $\begin{array}{c}\text { Mothers } \\
(\mathbf{n}=\mathbf{2 3})\end{array}$ & $\mathbf{n}(\%)$ & $\begin{array}{c}\text { Sister1 } \\
(\mathbf{n}=\mathbf{1 7})\end{array}$ & $\mathbf{n}(\%)$ & $\begin{array}{c}\text { Sister2 } \\
(\mathbf{n}=9)\end{array}$ & $\mathbf{n}(\%)$ \\
\hline P5 & 150.7 & 149.0 & 150.5 & $0(0.0)$ & 148.4 & $5(21.7)$ & 147.0 & $1(5.9)$ & 153.0 & $0(0.0)$ \\
P10 & 152.2 & 151.0 & 151.6 & $2(8.7)$ & 150.0 & $2(8.7)$ & 151.0 & $1(5.9)$ & 153.0 & $0(0.0)$ \\
P25 & 156.2 & 155.4 & 156.2 & $4(17.4)$ & 151.0 & $4(17.4)$ & 155.5 & $3(17.6)$ & 154.5 & $3(33.3)$ \\
P50 & 159.7 & 160.6 & 159.2 & $6(26.1)$ & 158.0 & $7(30.4)$ & 159.0 & $4(23.5)$ & 164.0 & $1(11.1)$ \\
P75 & 163.9 & 165.1 & 166.1 & $3(13.0)$ & 159.0 & $4(17.4)$ & 164.5 & $2(11.8)$ & 164.5 & $0(0.0)$ \\
P90 & 168.0 & 169.0 & 170.1 & $3(13.0)$ & 162.6 & $1(4.3)$ & 168.0 & $6(35.3)$ & 166.0 & $5(55.6)$ \\
P95 & 169.5 & 170.6 & 172.0 & $5(21.7)$ & 164.2 & $0(0.0)$ & 168.0 & $0(0.0)$ & 166.0 & $0(0.0)$ \\
\hline
\end{tabular}


TABLE 3 - Explicative regression for adult height estimation of former gymnasts.

\begin{tabular}{|c|c|c|c|c|c|c|c|c|c|c|}
\hline Only model & B & $\begin{array}{l}\text { Std. } \\
\text { Error }\end{array}$ & Beta & $\mathrm{t}$ & Sig. & $\mathrm{R}$ & $\mathrm{R}^{2}$ & Adj $R^{2}$ & SEE & $\begin{array}{l}\text { Durbin-Watson } \\
\text { (Residual analy.) }\end{array}$ \\
\hline (Constant) & 24.491 & 38.508 & & 0.636 & 0.532 & \multirow{2}{*}{0.611} & \multirow{2}{*}{0.373} & \multirow{2}{*}{0.343} & \multirow{2}{*}{5.3252} & \multirow{2}{*}{2.172} \\
\hline Heig Target (Tann.) & 0.869 & 0.246 & 0.611 & 3.536 & 0.002 & & & & & \\
\hline \multicolumn{2}{|c|}{ Excluded variables } & \multicolumn{2}{|l|}{ Beta in } & \multicolumn{2}{|l|}{$\mathrm{t}$} & \multicolumn{2}{|l|}{ Sig. } & \multicolumn{2}{|c|}{ Partial R } & Tolerance \\
\hline \multicolumn{2}{|c|}{ Gymnasts menarche } & \multicolumn{2}{|l|}{0.294} & \multicolumn{2}{|l|}{1.665} & \multicolumn{2}{|l|}{0.111} & \multicolumn{2}{|c|}{0.349} & 0.882 \\
\hline \multicolumn{2}{|c|}{ Initial age of training } & \multicolumn{2}{|l|}{0.005} & \multicolumn{2}{|l|}{0.029} & \multicolumn{2}{|c|}{0.977} & \multicolumn{2}{|c|}{0.007} & 0.997 \\
\hline \multicolumn{2}{|l|}{ Practice time } & \multicolumn{2}{|l|}{-0.240} & \multicolumn{2}{|l|}{-1.373} & \multicolumn{2}{|c|}{0.185} & \multicolumn{2}{|c|}{-0.293} & 0.934 \\
\hline \multicolumn{2}{|l|}{ Weekly training } & \multicolumn{2}{|l|}{-0.054} & \multicolumn{2}{|l|}{-0.304} & \multicolumn{2}{|c|}{0.765} & \multicolumn{2}{|c|}{-0.68} & 1.000 \\
\hline \multicolumn{2}{|l|}{ Time out } & \multicolumn{2}{|l|}{0.092} & \multicolumn{2}{|l|}{0.449} & \multicolumn{2}{|c|}{0.659} & \multicolumn{2}{|c|}{0.100} & 0.737 \\
\hline \multicolumn{2}{|l|}{ Age time out } & \multicolumn{2}{|l|}{-0.181} & \multicolumn{2}{|l|}{-1.033} & 0.314 & & -0.2 & & 0.973 \\
\hline Father Stature & & 0.005 & & 0.014 & & 0.989 & & 0.0 & & 0.252 \\
\hline Mother Stature & & 0.003 & & -0.014 & & 0.989 & & -0.0 & & 0.621 \\
\hline
\end{tabular}

Stepwise (Criteria: Probability-of-F-to-enter <= 0.050 , Probability-of-F-to-remove $>=0.100$ ).

\section{Discussion}

The content of this study presents data on maturational aspect and growth among Brazilian women formerly involved in high-performance artistic gymnastics. The results revealed that at the current adult stage of life, the former gymnasts reached and some surpassed the percentiles of average height established by official organizations for the average population.

In the small amount of research conducted with former gymnasts, we point out BAss et al. ${ }^{35}$, who verified, in their study with Australian gymnasts who had been retired from training and competition for eight years, that the gymnasts presented an average height of $163.1 \mathrm{~cm}$; in other words, the equivalent of the 75 th percentile, which reinforces our findings. Especially regarding the percentile of the present group studied, the former gymnasts presented heights of $156.2 \mathrm{~cm}, 159.2 \mathrm{~cm}$, and $166.1 \mathrm{~cm}$, in the $25 \mathrm{th}$, 50th and 75th NCHS percentiles, respectively. However, the overall research on the height of gymnasts, which included those in pre-pubertal and pubertal stages, show that during their childhood and teenage years, the gymnasts already had a smaller stature, being below the 50th percentile, 8, 12, 21, 26-27.

Concerning the former gymnasts, the average age at menarche was 1.2 years later than their mothers and 1.5 years later than their sisters. The obtained data confirms the condition of delayed maturation of athletes in relation to the average population ${ }^{8,12,36}$. Delayed menarche age is expected in girl athletes when compared to the normal population. Nonetheless, the data dealing with the effects of intensive physical training on menarche involve a number of factors, it is difficult to implicate training as a factor which specifically delays menarche ${ }^{37}$, and it can affect the final adult height. However, on average, after 14 years of age, the gymnasts' growth becomes consistent albeit slow $^{21}$, which is typical of delayed adolescents, and in the post-puberal phase the gymnasts' height is close to the 50 th percentile $(159.66 \mathrm{~cm})$. Authors agreed that high height is a fundamental characteristic in the some high performance sport ${ }^{16-17,19-20}$, and "the advantages of individuals with a set anthropometric system is a result of natural and sporting selection" ${ }^{19}$, but not in AG, since low height and the lower centre of gravity can facilitate the execution of acrobatic movements ${ }^{38-40}$. In AG, most athletes have presented short height and studies have shown that this feature would be requisite, an adaptation to the environment (natural selection of this sport) rather than an effect of the actual training ${ }^{41}$. The genetic inheritance and the strict selection procedure in the high performance sport are pointed out as the main causes of the gymnasts' height. However, TABLE 3 showed that most of the variables excluded from the explanatory model involved aspects of training. The correlation between adult height and practice time $(-0.05)$, weekly training $(-0.04)$ years of time out $(-0.30)$ and age time out $(-0.11)$ although low. 
The statement of THEINTZ et al. ${ }^{7}$ that more than 18 weekly training hours might possibly interfere in the potential set for height has no support from the results obtained in our study (TABLE 1), nor in the other studies ${ }^{35-41}$. These authors state that they have found no evidence to prove that training would adversely affect the height development among AG athletes. DAMSGAARD et al. ${ }^{17}$, indicates that there is no set standard, which suggests that the possibility of training more than 18 hours a week interferes in the growth and maturation process. We recognize the limitations of the " $n$ " sample of this study to carry out a predictive regression, but our intention was to discuss the exclusion of variables, with the purpose of explanation.

All data seem to indicate that the myth of what causes lower height in the gymnasts is only based on the first impression of spectators and mass media. However, it is understandably not sufficiently informed about AG and the necessary characteristics for a high performance in this sport regarding volume, intensity of training, and mainly the advantages that the biodynamic aspects bring to the shorter athletes, such as, lower rotational inertia or moment of inertia ${ }^{19,39}$. So far, there is no consistent literary record of former adult gymnasts complaining about their low stature (whatever it may be) due to AG training. Our results showed that despite sexual maturity being delayed, the average height of the former gymnasts $(160.6 \mathrm{~cm})$ was around the 50th percentile set by the NCHS and IBGE, and above other percentiles in all comparisons, and especially that the height of the analysed group is within and above the patterns expected of their nuclear family (parents/sisters).

Our research was conducted after the final adult height was attained, when practically all the effects of the maturation over the growth process had been registered in uncommon studies of AG growth. Possibly, that fact led to the skewed belief that the AG athletes would not grow since delayed maturation did not allow people to see the attainment of the adult height predicted. This was confirmed in a recent review commissioned by the International Gymnastics Federation (FIG), which revised the current literature and addressed questions about the growth of gymnasts ${ }^{41}$.

Height and body weight are variables which attract the interest of coaches due to its association with high performance ${ }^{39,42}$. In Brazil ${ }^{43}$ the short height presented by the WAG athletes has been a reason of concern, since it has been generating a certain prejudice in relation to this sport. In other words, many parents will withdraw their daughters from practicing AG based on the belief that training may adversely affect their adult height in the adult stage.

Nevertheless, special attention must be given to the adolescent when fluctuations above or below the percentile recorded in childhood years perhaps arise due to different individual rhythms (early, normal, and late growth) going through the peak height velocity. These differences may cause an individual in the prepubertal and/or a pubertal phase(s) to be temporarily above or below the percentile verified during childhood development. The phenomenon indicates, respectively, a precocious or delayed rhythm of going through this event and makes the adult height estimate prone to inaccuracy when the momentary observation of height is the only reference and does not take into account other indicators and/or additional maturational aspects (i.e. sexual maturation) $)^{20,41}$.

This study encountered a limitation regarding a small test group from the southeast, but it is where the most gymnasts' population is concentrated in Brazil. Although they have been elite athletes and members of major teams in international competitions, it would be recommended that Sport Sciences researchers conduct similar studies with other populations. Scientifically supported research may clarify questions involving the myth of the low height of athletes in AG, which still prevails, particularly, in our country.

This study was designed to identify the height profile and the maturational and training history of former WAG adult athletes in Brazil. Contrary to the popular belief, on average, the gymnasts were taller than their mothers and sisters, though with a relatively late age of menarche. In relation to patterns of Brazilian and international population growth, the relative values of the adult height of gymnasts were always above the standards, with the exception of the 50th percentile, when the value was slightly lower. As a retrospective study, the effects of maturation on the growth process are eliminated when the comparison of adult height reached by former gymnasts is allowed. The final height of these former gymnasts was confirmed to have not been affected by the AG intensive high performance training. 


\section{Resumo}

0 impacto do treinamento de alta intensidade sobre a estatura adulta de ginastas de alto nível: um estudo retrospectivo

0 objetivo deste estudo foi identificar o potencial impacto do treinamento de alta intensidade sobre as caracteristicas antropométricas e maturacionais de ex-atletas da ginástica artística feminina e comparar a estatura adulta com padrões internacionais de crescimento. Uma amostra composta de 23 ex-atletas de elite da ginástica artística feminina brasileira foi avaliada. A partir de uma retrospectiva histórica média de 29,56 anos, foi determinado o tempo médio de formação $[9,3(2,6)$ anos], horas semanais de treinamento $[24,26(4,2)]$ e tempo após encerramento da carreira competitiva $(13,61 \pm 5,12$ anos). A partir dos dados antropométricos das ginastas (quando ativas), o alvo parental da estatura das ex-atletas, de suas irmãs mais velhas (1) e mais jovens (2) foi calculado pelo método de Tanner \{[(Altura do pai $-13 \mathrm{~cm}$ ) + Altura da mãe] $\div 2\}$. Além disso, o histórico de treino, idade de ocorrência da menarca e classificação do crescimento segundo os padrões internacionais, foram registrados para comparações. A estatura média das ex-atletas apresentou normalidade esperada para estatura adulta (NCHS), e em alguns casos ultrapassaram os valores dos percentis 75\%, 90\% e 95\%. As ex-atletas foram maiores do que suas mães $(p=0,039)$, mas não diferiram da irmã $1(0,952)$ ou irmã $2(p=0,998)$. A idade da menarca daquelas foi significantemente mais tardia do que de suas irmãs $1(p=0,008)$ e $2(p=0,017)$. Em relação às referências brasileiras (IBGE), a altura final das ex-ginastas foi sempre maior do que 0 padrão nacional, ligeiramente menor do que suas irmãs 2 em alguns momentos (centis 5 e 10), mas eram mais altas do que suas mães e irmãs 1 . Em conclusão, não há evidências de que o treinamento de alto impacto da ginástica artística resulte em efeitos adversos sobre a estatura adulta final das atletas.

PalavRas-chave: Crescimento; Maturação biológica; Ginástica artística feminina; Alto rendimento; Treinamento esportivo; Antropometria.

\section{References}

1. Malina RM, Katzmarzyk PT, Beunen G. Birth weight and its relationship to size attained and relative fat distribution at 7 to 12 years of age. Obes Res. 1996;4:385-90.

2. Jemni M, Sands WA, Friemel F, Delamarche P. Effect of active and passive recovery on blood lactate and performance during simulated competition in high level gymnasts. Can J Appl Physiol. 2003;28:240-56.

3. Meira TB, Nunomura M. Interação entre leptina, ginástica artística, puberdade e exercício em atletas do sexo feminino. Rev Bras Cienc Esporte. 2010;32:185-99.

4. Jemni M. The science of gymnastics. New York: Routledge; 2011.

5. Claessens AL, Malina RM, Lefevre J, et al. Growth and menarcheal status of elite female gymnasts. Med Sci Sports Exerc. 1992;24:755-63.

6. Pool J, Binkhors.Ra, Vos JA. Some anthropometric and physiological data in relation to performance of top female gymnasts. Int Z Angew Physiol. 1969;27:329.

7. Theintz GE, Howald H, Weiss U, Sizonenko PC. Evidence for a reduction of growth-potential in adolescent female gymnasts. J Pediatr. 1993;122:306-13.

8. Georgopoulos NA, Theodoropoulou A, Roupas ND, et al. Final height in elite male artistic gymnasts. J Pediatr Endocr Met. 2012;25:267-71.

9. Weimann E, Blum WF, Witzel C, Schwidergall S, Bohles HJ. Hypoleptinemia in female and male elite gymnasts. Eur J Clin Invest. 1999;29:853-60.

10. Caine D, Lewis T, O’Connor T, Howe W, Bass S. Does gymnastics training inhibit growth of females? Clin J Sport Med. 2001;11:260-70.

11. Luo ZC, Low LCK, Karlberg J. Critical growth phases for adult shortness in Hong Kong Chinese. J Pediatr Endocr Met. 2001;14:757-65. 
Ferreira-Filho RA, et al.

12. Erlandson MC, Sherar LB, Mirwald RL, Maffulli N, Baxter-Jones ADG. Growth and maturation of adolescent female gymnasts, swimmers, and tennis players. Med Sci Sports Exerc. 2008;40:34-42.

13. Burt LA, Naughton GA, Greene DA, Courteix D, Ducher G. Non-elite gymnastics participation is associated with greater bone strength, muscle size, and function in pre- and early pubertal girls. Osteoporos Int. 2012;23:1277-86.

14. Jaffre C, Lac G, Benhamou CL, Courteix D. Effects of chronic intensive training on androgenic and cortisol profiles in premenarchal female gymnasts. Eur J Appl Physiol. 2002;87:85-9.

15. Poyrazoglu S, Darendeliler F, Bas F, et al. Target height estimation in children with idiopathic short stature who are referred to the growth clinic. Horm Res. 2009;72:178-83.

16. Bompa T, Di Pasquale M, Cornacchia L. Serious strength training. 2nd ed. Champaign: Human Kinetics; 2002.

17. Damsgaard R, Bencke J, Matthiesen G, Petersen JH, Muller J. Is prepubertal growth adversely affected by sport? Med Sci Sports Exerc. 2000;32:1698-703.

18. Malina R, Bouchard C, Bar-Or O. Growth, maturation \& physical activity. 2nd ed. Champaign: Human Kinetics; 2003.

19. Arkaev LI, Suchilin NG. How to create champions: the theory and methodology of training top-class gymnasts. Oxford: Meyer \& Meyer; 2004.

20. Malina RM, Bouchard C, Bar-Or O. Growth, maturation and physical activity. 2nd ed. Champaign: Human Kinetics; 2004.

21. Daly RM, Bass S, Caine D, Howe W. Does training affect growth? Answers to common questions. Phys Sportsmed. 2002;30:21-9.

22. Theodoropoulou A, Markou KB, Vagenakis GA, et al. Delayed but normally progressed puberty is more pronounced in artistic compared with rhythmic elite gymnasts due to the intensity of training. J Clin Endocrinol Metab. 2005;90:6022-7.

23. Al-Sendi AM, Shetty P, Musaiger AO. Anthropometric and body composition indicators of Bahraini adolescents. Ann Hum Biol. 2003;30:367-79.

24. Malina RM, Reyes ME, Tan SK, Little BB. Physical fitness of normal, stunted and overweight children 6-13 years in Oaxaca, Mexico. Eur J Clin Nutr. 2011;65:826-34.

25. Norton K, Olds T. Antropométrica. Porto Alegre: Armed; 2005.

26. Baxter-Jones AD, Maffulli N, Group TS. Parental influence on sport participation in elite young athletes. J Sports Med Phys Fitness. 2003;43:250-5.

27. Baxter-Jones AD. Growth and development of young athletes. Should competition levels be age related? Sports Med. 1995;20:59-64.

28. Lohman TG, Roche AF, Martorell R. Anthropometric standardization reference manual. Champaign: Human Kinetics; 1988.

29. Tanner JM, Goldstein H, Whitehouse RH. Standards for children's height at ages 2-9 years allowing for heights of parents. Arch Dis Child. 1970;45:755-62.

30. Pescovitz OH, Eugster EA. Pediatric endocrinology: mechanisms, manifestations, and management. Philadelphia: LWW; 2004.

31. Brook C, Clayton P, Brown R. Brook’s clinical pediatric endocrinology. Malden: Blackwel; 2005.

32. Peltenburg AL, Erich WBM, Zonderland ML, Bernink MJE, Vandenbrande JL, Huisveld IA. A retrospective growth study of female gymnasts and girl swimmers. Int J Sports Med. 1984;5:262-7.

33. McDowell MA, Fryar CD, Ogden CL, Flegal KM. Anthropometric reference data for children and adults: United States, 2003-2006. Natl Health Stat Report. 2008;10:1-48. Available from: http://www.cdc.gov/nchs/data/nhsr/nhsr010.pdf.

34. Instituto Brasileiro de Geografia e Estatística. Diretoria de Pesquisas. Coordenação de Trabalho e Rendimento. Dados amostrais e estimativas populacionais [Internet]. Pesquisa de Orçamentos Familiares 2008-2009. Rio de Janeiro: IBGE; 2011. [citado 29 out. 2015]. Disponível em: http://www.ibge.gov.br.

35. Bass S, Bradney M, Pearce G, Hendrich E, Inge K, Stuckey S, et al. Short stature and delayed puberty in gymnasts: influence of selection bias on leg length and the duration of training on trunk length. J Pediatr. 2000;136:149-55.

36. Lindholm C, Hagenfeldt K, Ringertz BM. Pubertal development in elite juvenile gymnasts: effects of physical training. Acta Obstet Gynecol Scand. 1994;73:269-73.

37. Malina R. Menarche in atheletes: a synthesis and hypothesis. Ann Hum Biol. 1983;10:1-24.

38. Malina RM, Peña Reyes ME, Chávez GB, Little BB. Weight status of indigenous youth in Oaxaca, southern Mexico: concordance of IOTF and WHO criteria. Ann Hum Biol. 2013;40:426-34.

39. Nunomura M, Oliveira MS. Talent detection and selection in women's artistic gymnastics: the Brazilian coaches' perspective. Rev Bras Ciênc Esporte- 2014;36:311-25.

40. Barker-Ruchti N. Ballerinas and pixies: a genealogy of the changing female gymnastics body. Int J Hist Sport. 2009;26:45-62.

94 • Rev Bras Educ Fís Esporte, (São Paulo) 2016 Jan-Mar; 30(1):87-95 
41. Malina RM, Baxter-Jones AD, Armstrong N, Beunen GP, Caine D, Daly RM, et al. Role of intensive training in the growth and maturation of artistic gymnasts. Sports Med. 2013;43:783-802.

42. Weineck J. Biologia do esporte. 7a ed. Barueri: Manole; 2005.

43. Ferreira-Filho RA, Nunomura M, Tsukamoto MHC. Ginástica artística e estatura: mitos e verdades na sociedade brasileira. Rev Mackenzie Educ Fís Esporte. 2006;5:21-31.

\section{Acknowledgments}

The study was part of a R. F.-F. Master Research Project at the School of Physical Education and Sport, University of Sao Paulo. We thank to the eliteformerathletes involved in this study and Brazilian Gymnastics Confederation for allowing access to anthropometric data.

\begin{tabular}{r|r} 
ENDEREÇo & \\
Dalmo Roberto Lopes Machado & Recebido para publicação: 16/10/2015 \\
Física e Esporte de Ribeirão Preto & Aceito: 07/12/2015 \\
Universidade de São Paulo & \\
Av. dos Bandeirantes, 3900 & \\
- Ribeirão Preto - SP - BRASIL & \\
e-mail: dalmo@usp.br &
\end{tabular}

